\title{
Comprehensive treatment of unresectable cardiac angiosarcoma: A case report and review of literature
}

\author{
CHAO WANG $^{1}$, MIN SHI $^{1}$, CHEN YANG $^{1}$, TAO MA $^{1}$, JINLING JIANG $^{1}$, \\ YING LIU $^{1}$, WENQI XI ${ }^{1}$, ZHENGGANG ZHU ${ }^{1,2}$ and JUN ZHANG ${ }^{1}$ \\ Departments of ${ }^{1}$ Oncology and ${ }^{2}$ Surgery, Shanghai Key Laboratory of Gastric Neoplasms, Shanghai Institute of \\ Digestive Surgery, Ruijin Hospital, Shanghai Jiao Tong University School of Medicine, Shanghai 200025, P.R. China
}

Received February 16, 2017; Accepted June 28, 2017

DOI: $10.3892 /$ mco.2017.1390

\begin{abstract}
Cardiac angiosarcoma is a rare but lethal tumor that is difficult to diagnose and treat, due to its rapid local relapse and high incidence of systemic metastasis. The prognosis of cardiac angiosarcoma is dismal, with a mean life expectancy of only a few months. We herein report a case of unresectable angiosarcoma arising from the right atrium. The patient received first-line chemotherapy with weekly paclitaxel, and second-line therapy with vinorelbine and bevacizumab upon disease progression. The progression-free survival was 6 months and the overall survival was 7 months. The patient eventually succumbed to respiratory failure. A study of the present case and a review of the relevant literature suggest that treatment decisions for unresectable locally advanced or metastatic cardiac angiosarcoma are difficult, as the published literature on this disease mainly consists of case reports without sufficient data. Therefore, further clinical trials specific to the treatment of unresectable cardiac angiosarcoma are warranted.
\end{abstract}

\section{Introduction}

Primary cardiac neoplasms are rare, with an incidence of $\sim 0.2 \%$. Primary cardiac angiosarcoma (PCA) comprises $2 \%$ of all primary cardiac neoplasms (including benign tumors) and is the most common primary malignant cardiac tumor $(1,2)$. PCA typically presents between the third and fifth decades of life, most often arising in the right atrium (RA) and infiltrating the pericardium, which may cause right-sided heart failure or tamponade, usually with superimposed systemic signs, such as fever, night sweats, chills, fatigue and weight loss. Pericardiocentesis yields bloody fluid that often does not

Correspondence to: Professor Jun Zhang, Department of Oncology, Shanghai Key Laboratory of Gastric Neoplasms, Shanghai Institute of Digestive Surgery, Ruijin Hospital, Shanghai Jiaotong University School of Medicine, 197 Ruijiner Road, Shanghai 200025, P.R. China

E-mail: junzhang10977@sjtu.edu.cn

Key words: bevacizumab, paclitaxel, vinorelbine, cardiac angiosarcoma contain malignant cells, even when the tumor cells have invaded the pericardium (3). Diagnostic assessment includes tissue biopsy followed by histological confirmation, transthoracic echocardiography (TTE) to determine the tumor dimensions, pericardial status and cardiac function, computed tomography (CT) imaging to exclude metastatic disease, magnetic resonance imaging (MRI) to depict the extracardiac extent of the disease and delineate the extent of the primary lesion; positron emission tomography (PET) imaging may also be useful for detecting metastases when radical surgery is planned $(2,4)$. However, even radical surgery often yields unsatisfactory results, as $>90 \%$ of the patients succumb to the disease within 1 year (5). Comprehensive treatment includes neoadjuvant or adjuvant chemotherapy, radiotherapy or targeted therapy with complete surgical resection; even orthotopic heart transplantation may prove beneficial for the patients (6). We herein report a case of unresectable PCA originating in the RA. The patient received first-line chemotherapy with weekly paclitaxel, and second-line therapy with vinorelbine and bevacizumab when the disease progressed. The relevant literature was also reviewed, to compare and summarize the treatment of unresectable locally advanced or metastatic PCA.

\section{Case report}

In June 2015, a healthy 41-year-old Chinese woman complained of a 2-month progressive shortness of breath and chest discomfort for no apparent reason, which was relieved by rest. There was no precordialgia, no radiating back pain, no headache or dizziness, and no edema in the lower extremities. The previous medical history revealed that the patient had presented with unexplained pericardial effusion and underwent pericardiocentesis; however, analysis of the pericardial fluid failed to determine the etiology. On auscultation, there were no heart murmurs or lung rales, with the exception of a pericadial rub. The results of the laboratory tests were as follows: Carbohydrate antigen (CA)125 $435.70 \mathrm{U} / \mathrm{ml}$ (normal, <35.00 U/ml), CA199 $12.70 \mathrm{U} / \mathrm{ml}$ (normal, $<35.00 \mathrm{U} / \mathrm{ml}$ ), carcinoembryonic antigen (CEA) $1.69 \mathrm{ng} / \mathrm{ml}$ (normal, $<5.00 \mathrm{ng} / \mathrm{ml}$ ) and neuron-specific enolase $32.51 \mathrm{ng} / \mathrm{ml}$ (normal, $<17.00 \mathrm{ng} / \mathrm{ml})$. TTE revealed a large mass $(6.7 \times 3.7 \mathrm{~cm})$, originating from the free wall of the RA, of which the lower part entered the right ventricle (RV) during diastole (Fig. 1A), accompanied by a massive pericardial effusion. Chest X-ray 

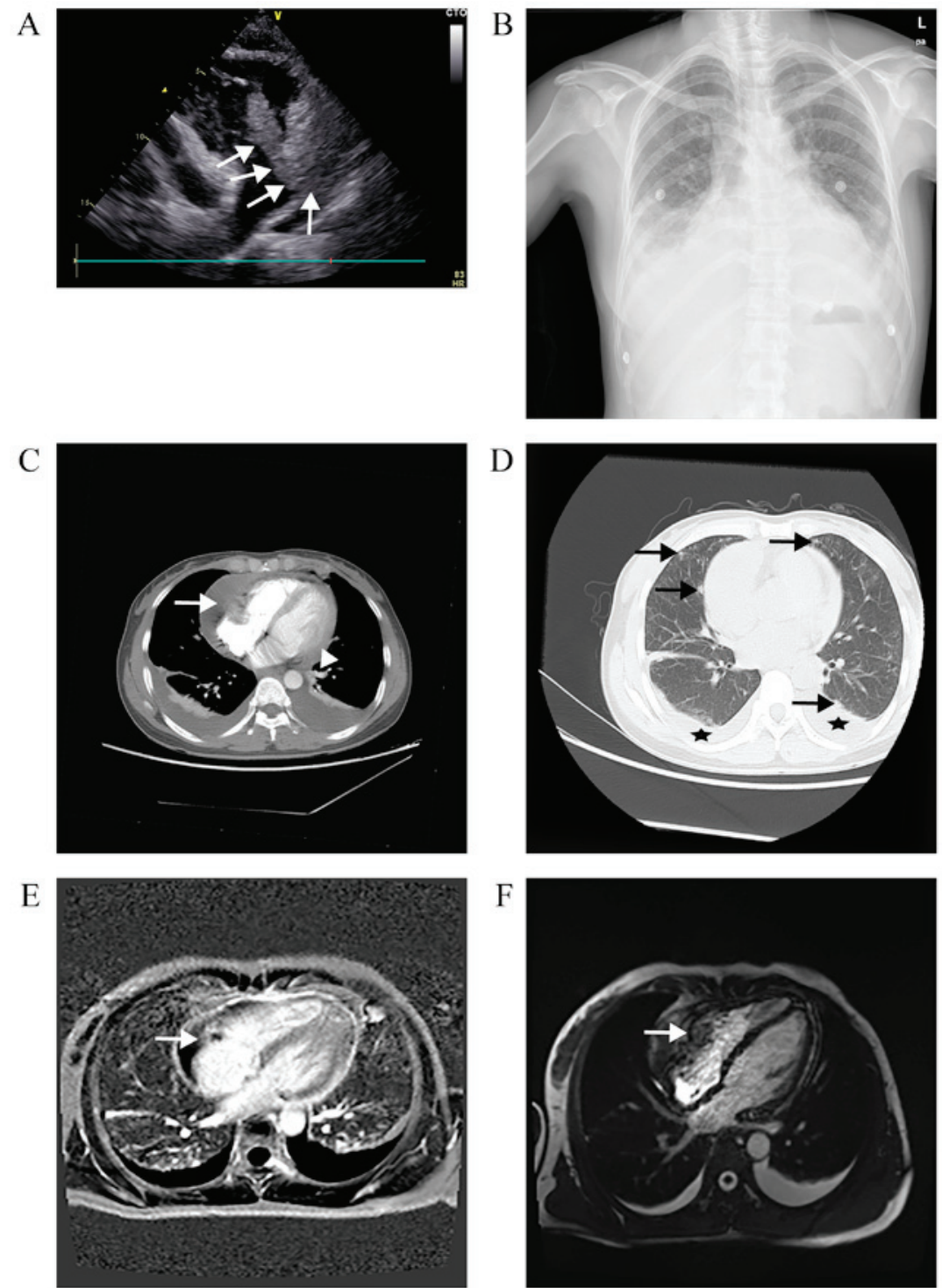

Figure 1. Imaging examinations. (A) Echocardiography demonstrated a dense lobed structure at the free wall of RA (arrows). (B) Chest X-ray revealed increased cardiothoracic ratio and costophrenic angle blunting. ( $\mathrm{C}$ and $\mathrm{D}$ ) Computed tomography revealed an inhomogeneous irregularly shaped mass infiltrating the RA (white arrow) and scattered pulmonary nodules (black arrows), pericardial effusion (white arrowhead) and bilateral pleural effusion (black asterisks). (E) Magnetic resonance imaging scan revealed that the tumor (arrow) had an isointense to high-intensity signal on T1-weighted images and (F) an isointense to low-intensity signal on T2-weighted images (white arrows). RA, right atrium.

revealed expansion of the heart shadow (cardiothoracic ratio, $70 \%$ ) and bilateral pleural effusion (blunting of the bilateral costophrenic angle; Fig. 1B). A CT scan confirmed the presence of a heterogeneous irregularly shaped mass infiltrating the RA, and also detected bilateral pulmonary nodules (Fig. 1C and D). On MRI, the mass exhibited heterogeneous signal intensity enhancement on T1-weighted images, and flow void on T2-weighted images (Fig. 1E and F). The ${ }^{18} \mathrm{~F}$-fluorodeoxyglucose uptake in the tumor reached a standardized uptake value of 13.6 (Fig. 2B). PET-CT also revealed tumor metastasis to multiple organs, including the lungs and bones (Fig. 2A and C-G). CT-guided percutaneous biopsy of a left ilium metastasis revealed poorly differentiated spindle-shaped tumor cells with slit-like or irregular vascular channels containing red blood cells (RBCs; hematoxylin and eosin staining; magnification, $\mathrm{x} 400$ ). Immunohistochemically, the tumor cells were positive for CD31 and CD34 (magnification, x400; Fig. 3). Taken together, these findings confirmed the diagnosis of metastatic PCA (T2N1M1).
Although the patient's performance status score was 1 on the Eastern Cooperative Oncology Group scale, the tumor had metastasized to other internal organs and total excision of the cardiac tumor was anatomically impossible. Therefore, $90 \mathrm{mg} / \mathrm{m}^{2}$ paclitaxel was administered intravenously on days 1 , 8 and 15 of a 28-day cycle. Prior to the administration of paclitaxel, the patient received intravenous premedications, including dexamethasone $5 \mathrm{mg}$, cimetidine $400 \mathrm{mg}$ and phenergan $25 \mathrm{mg}$. Standard antiemetics (mainly palonosetron $0.25 \mathrm{mg}$ ) were prescribed by the treating physician when clinically indicated. Cycles could not be initiated unless the granulocyte count was $>1500 / \mu \mathrm{l}$ and the platelets were $>100,000 / \mu \mathrm{l}$. The treatment was well-tolerated by the patient, except for grade II neutropenia (white blood cells $2.41 \times 10^{9} / 1$, neutrophils $\left.1.06 \times 10^{9} / 1\right)$ and prophylactic granulocyte colony-stimulating factor was administered at $150 \mu \mathrm{g}$. In December 2015, TTE revealed a shrinkage in the cardiac tumor size $(1.5 \times 1.1 \mathrm{~cm})$ and absorption of the pericardial effusion. A CT scan, 

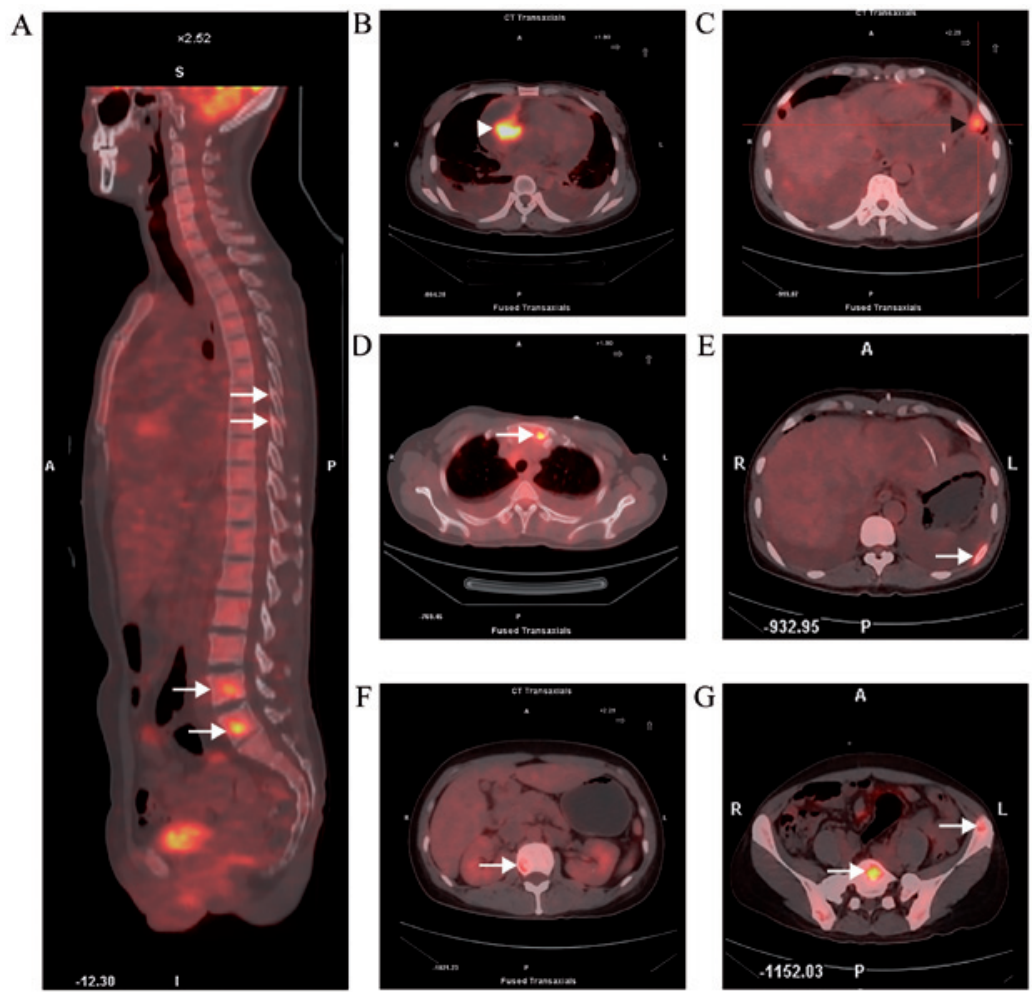

Figure 2. Positron emission tomography-computed tomography demonstrated multiple foci of abnormal activity in different organs and in the bones, including (A) the thoracic and lumbar vertebrae (white arrows), (B) heart (white arrowhead), (C) lung (black arrowhead), sacrum, ilium, (D) manubrium sterni (white arrow), (E) ribs (white arrow), (F) lumbar vertebrae (white arrow) and (G) sacrum and ilium (white arrow).
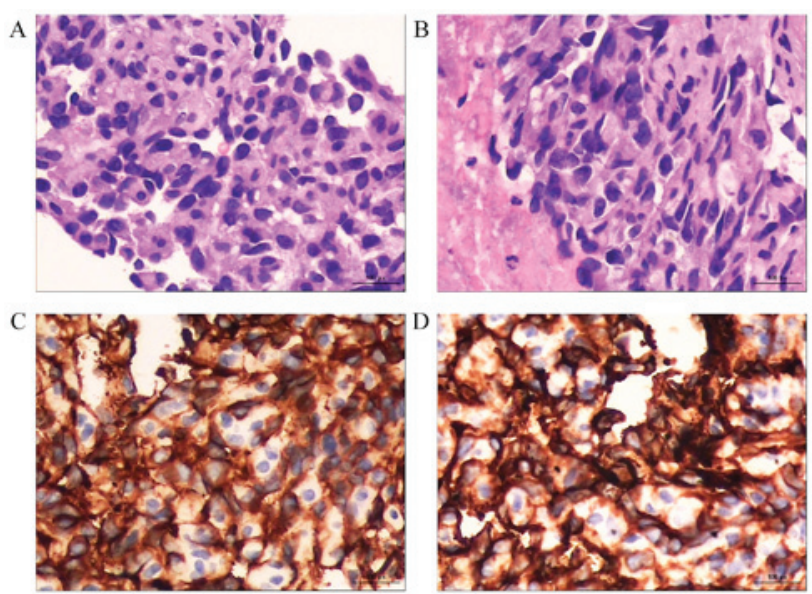

Figure 3. Pathological examination. (A and B) Hematoxylin and eosin stain (magnification, $\mathrm{x} 400$ ) of the biopsy specimen revealed poorly differentiated spindle-shaped tumor cells with slit-like or irregular vascular channels containing erythrocytes; (C) Immunohistochemical staining for CD31 revealed positive endothelial cells (magnification, x400); (D) Immunohistochemical staining for CD34 revealed positive endothelial cells (magnification, $\mathrm{x} 400$ ).

however, revealed that the volume of the pulmonary nodules had increased and identified new foci in the liver (Fig. 4). On laboratory tests the CA125 level was $19.00 \mathrm{U} / \mathrm{ml}$, the CA199 level was $37.60 \mathrm{U} / \mathrm{ml}$ and the CEA level was $8.13 \mathrm{ng} / \mathrm{ml}$. Therefore, vinorelbine was selected as second-line treatment, with $25 \mathrm{mg} / \mathrm{m}^{2}$ vinorelbine administered intravenously on days 1 and 8 of a 21-day cycle. In December 24, bevacizumab was added to the therapy scheme (vinorelbine $25 \mathrm{mg} / \mathrm{m}^{2}$ on days 1 and 8 of a 21-day cycle following administration of
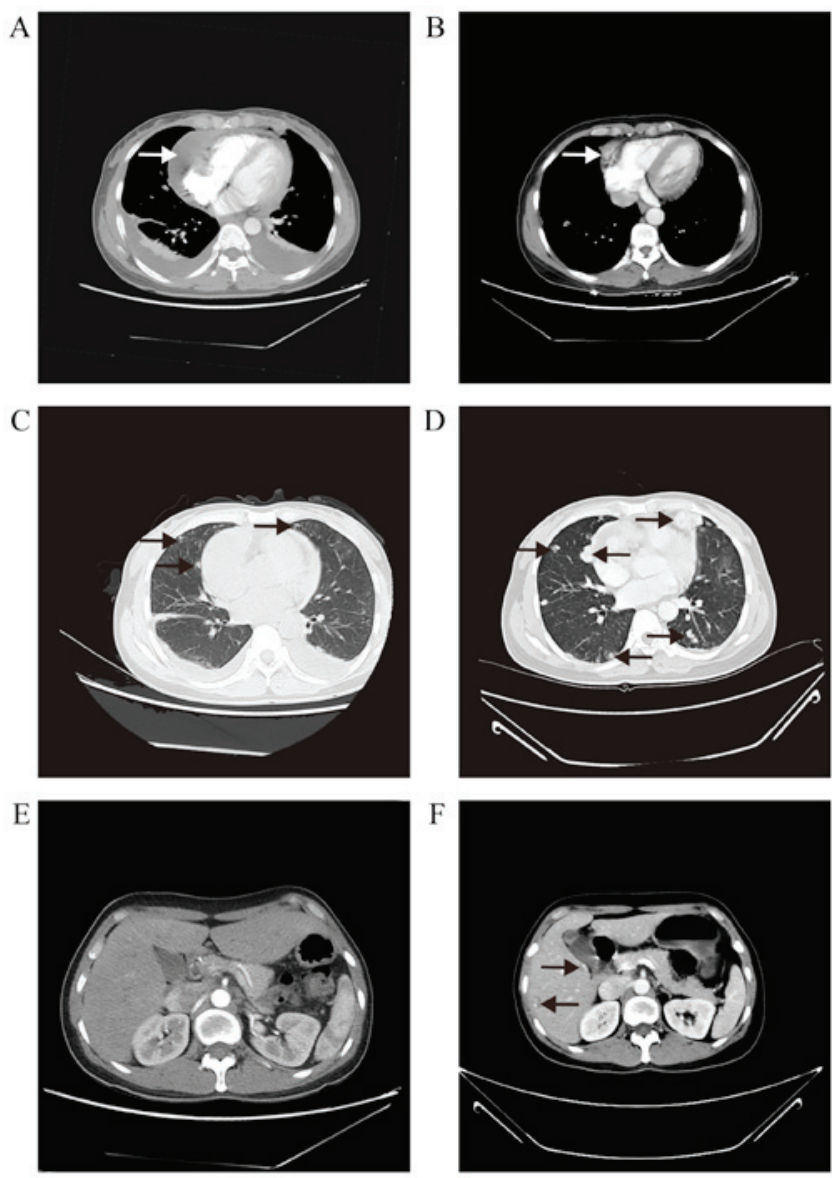

Figure 4. (A, C and E) Computed tomography scan of the heart (white arrow), lung and liver (black arrows) before treatment with weekly paclitaxel and (B, D and F) after the treatment. 
Table I. Cases of unresectable cardiac angiosarcoma reported in the English literature identified through a PubMed search.

\begin{tabular}{|c|c|c|c|c|c|}
\hline $\begin{array}{l}\text { First } \\
\text { author, year }\end{array}$ & Location & $\begin{array}{l}\text { Pericardial } \\
\text { extension }\end{array}$ & Treatment & $\begin{array}{l}\text { Outcome } \\
\text { (months) }\end{array}$ & (Refs.) \\
\hline Ram Prabu, 2011 & RA & Yes & Weekly paclitaxel $\left(80 \mathrm{mg} / \mathrm{m}^{2}\right)$ & PFS $16^{\mathrm{a}}$ & (5) \\
\hline Suderman, 2011 & LA & Yes & $\begin{array}{l}\text { Weekly docetaxel }\left(25 \mathrm{mg} / \mathrm{m}^{2}\right) \text { and } \\
\text { radiotherapy }\end{array}$ & $\begin{array}{l}\text { PFS } 16, \\
\text { OS } 22\end{array}$ & (7) \\
\hline Kodali, 2006 & RA & Yes & $\begin{array}{l}\text { Doxil } 40-50 \mathrm{mg} / \mathrm{m}^{2} \mathrm{q} / 4 \text { weeks } \\
\text { (line } 1), \text { MAID regimen }{ }^{\mathrm{b}} \text { (line } 2 \text { ) }\end{array}$ & $\begin{array}{l}\text { PFS } 15 \\
\text { OS } 16\end{array}$ & (8) \\
\hline Hata, 2011 & RA & No & $\begin{array}{l}\text { CRT ( } 30 \text { fractions of } 2 \text { Gy) with } \\
\text { weekly carboplatin (area under } \\
\text { the curve=2) and PTX }\left(60 \mathrm{mg} / \mathrm{m}^{2}\right)\end{array}$ & $\operatorname{PFS} 5^{\mathrm{a}}$ & (9) \\
\hline Franceschini, 2013 & RA & Yes & $\begin{array}{l}\text { Epirubicin }\left(60 \mathrm{mg} / \mathrm{m}^{2}\right) \text {, ifosfamide } \\
\left(3,000 \mathrm{mg} / \mathrm{m}^{2}\right) \text { and radiocherapy } \\
60 \mathrm{~Gy}\end{array}$ & $\operatorname{PFS~} 16^{\mathrm{a}}$ & (10) \\
\hline Fehr, 2010 & RA & No & $\begin{array}{l}\text { Doxorubicin }\left(75 \mathrm{mg} / \mathrm{m}^{2}\right) \text { and } \\
\text { ifosfamide }\left(7,500 \mathrm{mg} / \mathrm{m}^{2}\right) \\
\mathrm{q} / 3 \text { weeks (line } 1), \text { radiotherapy } \\
(22 \text { fractions of } 2 \mathrm{~Gy}) \text { and weekly } \\
\left.\text { paclitaxel }\left(80 \mathrm{mg} / \mathrm{m}^{2}\right) \text { (line } 2\right)\end{array}$ & $\begin{array}{l}\text { PFS } 8.5 \\
\text { OS } 12\end{array}$ & (11) \\
\hline Castilla, 2010 & RA & No & Paclitaxel $^{\mathrm{c}}$ & OS 9 & (12) \\
\hline \multirow[t]{2}{*}{ Batzios, 2006} & RV & No & $\begin{array}{l}\text { Epirubicin } 75 \mathrm{mg} / \mathrm{m}^{2}, \text { cisplatin } \\
80 \mathrm{mg} / \mathrm{m}^{2} \text { and ifosfamide } 2 \mathrm{gr} / \mathrm{m}^{2}, \\
\text { plus uromitexan } 800 \mathrm{mgx} 2\end{array}$ & & (13) \\
\hline & & & $\begin{array}{l}\text { Trastuzumab150 mg once weekly } \\
\text { and imatinib } 400 \mathrm{mg}\end{array}$ & $\begin{array}{l}\text { PFS 6, } \\
\text { OS } 7\end{array}$ & \\
\hline Aoka, 2004 & RA & Yes & $\begin{array}{l}\text { Carbon-ion radiotherapy } 64 \text { Gy } \\
\text { and interleukin } 2\end{array}$ & $\begin{array}{l}\text { PFS } 5 \\
\text { OS } 18^{\mathrm{a}}\end{array}$ & (14) \\
\hline Elsayad, 2016 & $\mathrm{RA}$ & No & $\begin{array}{l}\text { Radiotherapy } 55.8 \text { Gy and weekly } \\
\left.\text { paclitaxel }\left(50 \mathrm{mg} / \mathrm{m}^{2}\right) \text { (line } 1\right) \text {, } \\
\text { doxorubicin and isosfamide }{ }^{\mathrm{c}} \\
\text { (line } 2 \text { ) and pazopanib } \\
\text { (maintenance therapy) }\end{array}$ & $\begin{array}{l}\text { PFS } 3 \text {, } \\
\text { OS } 16^{\mathrm{a}}\end{array}$ & $(15,16)$ \\
\hline
\end{tabular}

${ }^{a}$ Time to data published. ${ }^{b}$ MAID regimen: Mesna, adriamycin, ifosfamide and dacarbazine. ${ }^{c}$ No detailed content on the treatment. OS, overall survival; PFS, progression-free survival; RA, right atrium; RV, right ventricle; LA, left atrium; CRT, chemoradiotherapy; PTX, paclitaxel.

bevacizumab $10 \mathrm{mg} / \mathrm{kg}$ on day 1). The patient complained of abdominal pain; thus, Oxycontin was administered at $30 \mathrm{mg} / 12 \mathrm{~h}$ to control the symptom. On January 8, 2016, the patient displayed anemia and respiratory failure (hemoglobin $56 \mathrm{~g} / \mathrm{l}, \mathrm{RBC}$ count $2.16 \times 10^{12}, \mathrm{PaO}_{2} 9.18 \mathrm{kPa}, \mathrm{PaCO}_{2} 4.63 \mathrm{kPa}$, $\mathrm{SpO}_{2} 91.5 \%$, actual base excess $18.9 \mathrm{mmol} / \mathrm{l}$, standard base excess $19.4 \mathrm{mmol} / 1$, D-dimer $40.00 \mathrm{mg} / \mathrm{l}$, and fibrin degradation products $128.1 \mathrm{mg} / \mathrm{l}$ ) and was unable to tolerate the chemotherapy; thus, a blood transfusion was performed, with oxygen inhalation and diprophylline injection. The patient succumbed to respiratory failure 7 months after diagnosis.

\section{Discussion}

Due to the rapid local relapse and high incidence of systemic metastasis, PCA has a dismal prognosis, with a mean life expectancy of only a few months. The literature focusing on the treatment of unresectable PCA was reviewed. Although the relevant studies were scarce, several case reports and results from phase II trials expanded our knowledge of this rare disease. A summary of most common locations, treatment modalities and outcome is presented in Table I. The cases included in the Table I were almost inoperable, which was undoubtedly among the key factors determining the patients' prognosis. Although there are currently no established guidelines for the treatment of angiosarcoma, no further subgroups have been identified by which adjuvant therapy could be recommended; as previously reported, chemotherapy, radiotherapy and targeted therapy are the most common choices for the treatment of unresectable PCA. In the present case, addition of radiotherapy to the second-line treatment was initially attempted, as several cases of PCA exhibited high sensitivity to radiotherapy (14-16); however, due to the patient's poor physical condition, radiotherapy had to be abandoned. Weekly paclitaxel has been reported to be effective in the treatment of unresectable angiosarcomas (including PCA), with a median progression-free survival (PFS) of 4 months and a median overall survival of 8 months (17). Vinorelbine 
has demonstrated antitumor activity in angiosarcoma, as monotherapy or combined with gemcitabine $(18,19)$. Bevacizumab is a recombinant humanized monoclonal IgG1 antibody that blocks the activity of vascular endothelial growth factor (VEGF)-A. A phase II trial concluded that bevacizumab is an effective and well-tolerated single-agent treatment for metastatic or locally advanced angiosarcoma (20). Several case reports demonstrated that combination therapy with bevacizumab and chemotherapy or radiotherapy may improve quality of life and survival in patients with metastatic angiosarcoma (21-25). In addition, another VEGF inhibitor, pazopanib, may prolong the PFS of metastatic non-adipocytic soft-tissue sarcoma after previous chemotherapy (26), particularly when used as maintenance therapy for PCA (16).

In conclusion, unresectable cardiac angiosarcomas are rare but lethal. In such cases, a multimodality approach including image-guided radiotherapy and targeted therapy may be considered, as the overall prognosis of these patients is poor. Further clinical trials focusing on the treatment of unresectable PCA are warranted.

\section{Acknowledgements}

The present study was supported by the National Science Foundation of China (grant nos. 81672327, 81372645, 81502013 and 81602411) and the Program of Shanghai Academic/Technology Research Leader (grant no. 17XD1402600), the Fong Shu Fook Tong Foundation and National Key Clinical Discipline (Oncology), the Shanghai Municipal Education Commission-Gaofeng Clinical Medicine Grant Support (grant no. 20161410), the Program for Outstanding Medical Academic Leader and Shanghai Municipal Commission of Health and Family Planning (grant no. 20154Y496).

\section{References}

1. Kurian KC, Weisshaar D, Parekh H, Berry GJ and Reitz B Primary cardiac angiosarcoma: Case report and review of the literature. Cardiovasc Pathol 15: 110-112, 2006.

2. Kupsky DF, Newman DB, Kumar G, Maleszewski JJ, Edwards WD and Klarich KW: Echocardiographic features of cardiac angiosarcomas: The mayo clinic experience (1976-2013). Echocardiography 33: 186-192, 2016.

3. Araoz PA, Eklund HE, Welch TJ and Breen JF: CT and MR imaging of primary cardiac malignancies. Radiographics 19: 1421-1434, 1999

4. Young RJ, Brown NJ, Reed MW, Hughes D and Woll PJ: Angiosarcoma. Lancet Oncol 11: 983-991, 2010.

5. Ram Prabu MP, Thulkar S, Ray R and Bakhshi S: Primary cardiac angiosarcoma with good response to Paclitaxel. J Thorac Oncol 6: 1778-1779, 2011

6. Pigott C, Welker M, Khosla P and Higgins RS: Improved outcome with multimodality therapy in primary cardiac angiosarcoma. Nat Clin Pract Oncol 5: 112-115, 2008.

7. Suderman D, Cooke A, Wong R and Klein J: Treatment of cardiac angiosarcoma with radiation and docetaxel: A case report with partial response and prolonged stable disease. J Thorac Oncol 6: 834-835, 2011

8. Kodali D and Seetharaman K: Primary cardiac angiosarcoma. Sarcoma 2006: 39130, 2006.

9. Hata A, Katakami N, Fujita S, Kokubo M and Imai Y: Angiosarcoma arising from right atrium: Remarkable response to concurrent chemoradiotherapy with carboplatin and paclitaxel. J Thorac Oncol 6: 970-971, 2011.
10. Franceschini D, Scotti V, Simontacchi G, Meattini I, Paiar F, Greto D, Bonomo P, Franzese C, Di Cataldo V, Pallotta S and Biti G: Application of helical tomotherapy for the treatment of a right atrium angiosarcoma: A case report. Tumori 99: e233-e236, 2013.

11. Fehr M, Kuhn M, Mayer K, Padberg B, Ulmer U and Cathomas R: Metastatic angiosarcoma arising from the right atrium: Unusual presentation and excellent response to treatment in a young patient. J Thorac Oncol 5: 1301-1302, 2010.

12. Castilla E, Pascual I, Roncalés F, Aguirre E and Del Río A: Transient response of cardiac angiosarcoma to paclitaxel. Eur J Cancer Care (Engl) 19: 699-700, 2010.

13. Batzios S, Michalopoulos A, Kaklamanis L, Stathopoulos J, Christopoulou M, Koutantos J and Stathopoulos GP: Angiosarcoma of the heart: Case report and review of the literature. Anticancer Res 26: 4837-4842, 2006.

14. Aoka Y, Kamada T, Kawana M, Yamada Y, Nishikawa T, Kasanuki $\mathrm{H}$ and Tsujii H: Primary cardiac angiosarcoma treated with carbon-ion radiotherapy. Lancet Oncol 5: 636-638, 2004.

15. Elsayad K, Lehrich P, Yppaerilae-Wolters H, Dieckmann C, Kriz J, Haverkamp U and Eich HT: Primary cardiac angiosarcoma treated with positron emission tomography/magnetic resonance imaging-guided adaptive radiotherapy. Can J Cardiol 32: 829. e7-829.e10, 2016

16. Elsayad K, Scobioala S, Kriz J, Haverkamp U and Eich HT: Advances in image-guided radiation therapy for primary cardiac angiosarcoma: The role of PET-CT and MRI. Oncol Res Treat 39: 290-294, 2016.

17. Penel N, Bui BN, Bay JO, Cupissol D, Ray-Coquard I, Piperno-Neumann S, Kerbrat P, Fournier C, Taieb S, Jimenez M, et al: Phase II trial of weekly paclitaxel for unresectable angiosarcoma: The ANGIOTAX study. J Clin Oncol 26: 5269-5274, 2008.

18. Anderson SE, Keohan ML, D'Adamo DR and Maki RG: A retrospective analysis of vinorelbine chemotherapy for patients with previously treated soft-tissue sarcomas. Sarcoma 2006: 15947, 2006.

19. Dileo P, Morgan JA, Zahrieh D, Desai J, Salesi JM, Harmon DC, Quigley MT, Polson K, Demetri GD and George S: Gemcitabine and vinorelbine combination chemotherapy for patients with advanced soft tissue sarcomas: Results of a phase II trial. Cancer 109: 1863-1869, 2007.

20. Agulnik M, Yarber JL, Okuno SH, von Mehren M, Jovanovic BD, Brockstein BE, Evens AM and Benjamin RS: An open-label, multicenter, phase II study of bevacizumab for the treatment of angiosarcoma and epithelioid hemangioendotheliomas. Ann Oncol 24: 257-263, 2013.

21. Yang P, Zhu Q and Jiang F: Combination therapy for scalp angiosarcoma using bevacizumab and chemotherapy: A case report and review of literature. Chin J Cancer Res 25: 358-361, 2013.

22. De Yao JT, Sun D, Powell AT and Rehmus EH: Scalp angiosarcoma remission with bevacizumab and radiotherapy without surgery: A case report and review of the literature. Sarcoma 2011: 160369,2011

23. Koontz BF, Miles EF, Rubio MA, Madden JF, Fisher SR, Scher RL and Brizel DM: Preoperative radiotherapy and bevacizumab for angiosarcoma of the head and neck: Two case studies. Head Neck 30: 262-266, 2008.

24. Jeng MR, Fuh B, Blatt J, Gupta A, Merrow AC, Hammill A and Adams D: Malignant transformation of infantile hemangioma to angiosarcoma: Response to chemotherapy with bevacizumab. Pediatr Blood Cancer 61: 2115-2117, 2014.

25. Nespereira-Jato MV, Peña-Panabad C, Quindós-Varela M and García-Silva J: Unresectable angiosarcoma treated with bevacizumab and paclitaxel. Actas Dermosifiliogr 105: 520-522, 2014.

26. van der Graaf WT, Blay JY, Chawla SP, Kim DW, Bui-Nguyen B, Casali PG, Schöffski P, Aglietta M, Staddon AP, Beppu Y, et al: Pazopanib for metastatic soft-tissue sarcoma (PALETTE): A randomised, double-blind, placebo-controlled phase 3 trial. Lancet 379: 1879-1886, 2012. 